\title{
Effect of dry period length and dietary energy source on energy balance, milk yield, and milk composition of dairy cows
}

\author{
A. T. M. van Knegsel, ${ }^{* 1}$ G. J. Remmelink, † S. Jorjong,‡ V. Fievez,‡ and B. Kemp* \\ ${ }^{*}$ Adaptation Physiology Group, Department of Animal Science, Wageningen University, PO Box 338, 6700 AH Wageningen, the Netherlands \\ †Livestock Research, Wageningen University and Research Centre, PO Box 65, 8200 AB Lelystad, the Netherlands \\ fLaboratory for Animal Nutrition and Animal Product Quality, Faculty of Bioscience Engineering, Ghent University, Proefhoevestraat 10, \\ 090 Melle, Belgium
}

\section{ABSTRACT}

The objective of this study was to evaluate the effects of dry period length and dietary energy source in early lactation on milk production, feed intake, and energy balance (EB) of dairy cows. Holstein-Friesian dairy cows (60 primiparous and 108 multiparous) were randomly assigned to dry period lengths $(0,30$, or 60 d) and early lactation ration (glucogenic or lipogenic), resulting in a $3 \times 2$ factorial design. Rations were isocaloric and equal in intestinal digestible protein. The experimental period lasted from $8 \mathrm{wk}$ prepartum to 14 wk postpartum and cows were monitored for milk yield, milk composition, dry matter intake (DMI), energy balance, and milk fat composition. Prepartum average milk yield for $60 \mathrm{~d}$ precalving was 13.8 and $7.7 \pm 0.5 \mathrm{~kg} / \mathrm{d}$ for cows with a 0 - and 30-d dry period, respectively. Prepartum DMI and energy intake were greater for cows without a dry period and 30-d dry period, compared with cows with a 60-d dry period. Prepartum EB was greater for cows with a 60-d dry period. Postpartum average milk yield until wk 14 was lower for cows without a dry period and a 30-d dry period, compared with cows with a 60-d dry period $(32.7,38.7$, and $43.3 \pm 0.7 \mathrm{~kg} / \mathrm{d}$ for $0-, 30-$, and $60-\mathrm{d}$ dry period, respectively). Postpartum DMI did not differ among treatments. Postpartum EB was greater for cows without a dry period and a 30-d dry period, compared with cows with a 60-d dry period. Young cows (parity 2) showed a stronger effect of omission of the dry period, compared with a 60-d dry period, on additional milk precalving (young cows: $15.1 \mathrm{~kg} / \mathrm{d}$; older cows: $12.0 \mathrm{~kg} / \mathrm{d}$ ), reduction in milk yield postcalving (young cows: 28.6 vs. $34.8 \mathrm{~kg} / \mathrm{d}$; older cows: 41.8 vs. $44.1 \mathrm{~kg} / \mathrm{d}$ ), and improvement of the EB postcalving (young cows: 120 vs. $-93 \mathrm{~kJ} / \mathrm{kg}^{0.75} \cdot \mathrm{d}$; older cows: -2 vs. $-150 \mathrm{~kJ} / \mathrm{kg}^{0.75} \cdot \mathrm{d}$. Ration did not affect milk yield and DMI, but a glucogenic ration tended to reduce milk

Received August 20, 2013.

Accepted November 25, 2013.

${ }^{1}$ Corresponding author: Ariette.vanKnegsel@wur.nl fat content and increased EB, compared with a more lipogenic ration. Reduced dry period length $(0$ and 30 d) increased the proportion of short- and medium-chain fatty acids in milk fat and omitting the dry period decreased the proportion of long-chain fatty acids in milk fat. In conclusion, shortening and omitting the dry period shifts milk yield from the postpartum to the prepartum period; this results in an improvement of the EB in early lactation. An increased energy status after a short dry period can be further improved by feeding a more glucogenic ration in early lactation.

Key words: dry period length, lipogenic nutrients, glucogenic nutrients, negative energy balance

\section{INTRODUCTION}

The advice to dry-off dairy cows at 6 to 8 wk before calving dates back to the early nineteenth century (Dix Arnold and Becker, 1936) and is well known to maximize milk production in the next lactation (e.g., Kuhn et al., 2005). Recently, the long tradition of a dry period for dairy cows was discussed (Collier et al., 2004). Shortening or omitting the dry period of dairy cows seems to shift milk production from the critical period shortly after calving to the weeks before calving, when the energy demands for milk production can be matched by feed intake easily (Grummer et al., 2010). This partial shift in milk production from post- to precalving can be hypothesized to improve the energy balance (EB) of dairy cows in early lactation. Indeed, shortening the dry period resulted in a significant improvement in EB in early lactation [-1.0 vs. $-1.7 \mathrm{MJ} / \mathrm{d}$ $(P<0.05)$; Rastani et al., 2005], whereas omitting the dry period resulted in absence of a negative EB during the first $56 \mathrm{~d}[0.2$ vs. $-1.7 \mathrm{MJ} / \mathrm{d}(P<0.01)$; Rastani et al., 2005] or first $4 \mathrm{wk}$ in lactation [0.38 vs. -0.46 $\mathrm{Mcal} / \mathrm{d}(P<0.01)$; de Feu et al., 2009], compared with a conventional dry period of $56 \mathrm{~d}$. These improvements in $\mathrm{EB}$ were realized by a reduction in milk production postcalving (Gulay et al., 2003; Rastani et al., 2005; de Feu et al., 2009). 
Although the number of studies that reported the EB of dairy cows after no or a short dry period is limited, some more studies reported consequences for metabolic health, disease incidence, and fertility. No or a short dry period reduced plasma concentrations of NEFA (Andersen et al., 2005; Klusmeyer et al., 2009) and BHBA (Schlamberger et al., 2010), and tended to increase plasma insulin concentration (Andersen et al., 2005; Mantovani et al., 2010) in early lactation, indicating reduced mobilization of body reserves and improved metabolic health. In addition, the incidence of ketosis was reduced when the dry period was omitted or shortened, whereas effects on other diseases in early lactation, such as mastitis and metritis, were more variable (Pezeshki et al., 2007; Schlamberger et al., 2010; Santschi et al., 2011a). Furthermore, several studies have indicated that shortening or omitting the dry period has potential to improve cow fertility (Gümen et al., 2005; Pezeshki et al., 2008; Watters et al., 2009).

Considering the potential beneficial effects for EB, metabolic health, and fertility, shortening or omitting the dry period can be argued to be a viable approach to manage health and fertility of high-producing dairy cows. Currently, however, application in practice is limited, possibly because of several questions and uncertainties concerning management of cows with a short or no dry period. First, because only a few studies are available (Rastani et al., 2005; de Feu et al., 2009), effects of omission of the dry period on EB need to be confirmed. Second, it can be hypothesized that complete adaptation of peripartum cow management, with adjustments in feeding and insemination strategies, may be essential for proper utilization of the concept of reducing the length of the dry period. For example, an earlier resumption of ovarian cyclicity related to a shorter dry period (Gümen et al., 2005) could have implications for the voluntary waiting period for breeding. Moreover, optimizing feeding strategies could potentially reduce milk yield losses or further improve the EB due to a short or no dry period.

Similar to reducing the dry period length, specific feeding strategies also are known to improve the EB by reducing milk energy output in early lactation. Earlier, we showed that glucogenic rations, compared with lipogenic rations, could reduce milk energy output and herewith improve the EB of dairy cows in early lactation (van Knegsel et al., 2007a), which was related to an increased plasma insulin concentration (van Knegsel et al., 2007b). Moreover, an improvement of EB was only observed when cows had relatively low plasma insulin concentration postpartum (i.e., primiparous cows with higher postpartum insulin concentration did not improve the EB or alter the insulin concentration as a result of a glucogenic ration). It can be hypothesized that when the EB in early lactation is positive due to omission of the dry period, plasma insulin concentration is increased and beneficial effects of glucogenic rations for dairy cow health are reduced because cows have less shortage in early lactation for glucogenic precursors, compared with cows with a conventional dry period and a more negative EB. In contrast, it can be hypothesized that when the EB is improved, but still negative, after a short dry period, a glucogenic ration can further improve the $\mathrm{EB}$ of dairy cows in early lactation. Therefore, the objective of this study was to evaluate the effects of dry period length $(0,30$, or $60 \mathrm{~d}$ dry) and dietary energy source (lipogenic and glucogenic) on milk production, feed intake, and EB of dairy cows in early lactation.

\section{MATERIALS AND METHODS}

\section{Experimental Design, Animals, and Housing}

The Institutional Animal Care and Use Committee of Wageningen University and Research Centre (Wageningen, the Netherlands) approved the experimental protocol. Holstein-Friesian dairy cows $(\mathrm{n}=168)$ were selected from the Dairy Campus Research dairy herd (Wageningen University and Research Centre Livestock Research, Lelystad, the Netherlands) for this experiment. The experiment started $9 \mathrm{wk}$ before the expected calving date and lasted until 14 wk postcalving. The experiment started with 60 primiparous cows, and 108 multiparous cows. Cows were blocked for parity (primiparous or multiparous), expected calving date, milk production in the previous lactation, and BCS and randomly assigned to treatments. Treatments consisted of dry period length $(0,30$, or $60 \mathrm{~d})$ and early lactation ration (glucogenic or lipogenic), resulting in a 3 $\times 2$ factorial arrangement of treatments. One cow (30 $\mathrm{d}$ dry and fed a lipogenic ration) was excluded from the experiment because of a mistake in the drying-off protocol. Cows were housed in a freestall with slatted floor and cubicles. During lactation, cows were milked twice daily (0500 and $1630 \mathrm{~h}$ ). The drying-off protocol for cows with the 30- and 60-d dry period consisted of a transition to the far-off ration at $\mathrm{d} 7$ before drying-off, and milking once daily at d 4 before drying-off cows. At drying-off, cows were treated with an intramammary antibiotic (Supermastidol; Virbac Animal Health, Barneveld, the Netherlands).

\section{Rations}

Prepartum, dry cows received a dry cow ration and lactating cows received a lactating cow ration supporting $25 \mathrm{~kg}$ of milk. From 3 wk prepartum onwards, all 
cows were fed $1 \mathrm{~kg} / \mathrm{d}$ of the experimental concentrate (lipogenic or glucogenic). Postpartum, the supply of experimental concentrates was $1 \mathrm{~kg}$ and increased stepwise by $0.5 \mathrm{~kg} / \mathrm{d}$ until experimental the concentrate supply reached $8.5 \mathrm{~kg} / \mathrm{d}$ at d 17 postpartum (pp). Experimental concentrates were provided by a computerized feeder located in the freestall. When lactating, cows received in the milking parlor $1 \mathrm{~kg} / \mathrm{d}$ of standard lactation concentrate. Forage composition did not differ among rations and was supplied ad libitum and consisted prepartum of grass silage, corn silage, wheat straw, and a protein source (rapeseed meal or soybean meal) in a ratio of 39:25:25:11 (DM basis). Postpartum, forage consisted of grass silage, corn silage, straw, and a protein source (rapeseed meal or soybean meal) in a ratio of 51:34:2:13 (DM basis). Ingredient and calculated chemical composition of concentrates are presented in Table 1. The chemical composition of the rations based on the realized total feed intake is presented in Table 2. Rations were isocaloric [net energy basis; Dutch net energy evaluation (VEM) system for dairy cows; Van Es, 1975] and equal in intestinal digestible protein and degraded protein balance [intestinal digestible protein/ degraded protein balance (DVE/OEB) system; Tamminga et al., 1994]. Concentrate and forage were supplied separately. Forage samples were taken weekly and stored at $-20^{\circ} \mathrm{C}$ until analysis. Before analyses (BLGG AgroXpertus BV, Oosterbeek, the Netherlands), forage samples were pooled per batch.

\section{$E B$ and Body Condition}

Body condition was scored (1-5 scale) every 4 wk. For dry cows, BW was recorded weekly. For lactating cows, BW was recorded after each milking and averaged per week. Milk production and feed intake (Insentec BV, Marknesse, the Netherlands) were recorded daily per cow from week -8 to 14 relative to calving and averaged per week. Energy balance was calculated according to the VEM system (Van Es, 1975; CVB, 2005) as the difference between VEM supplied with feed and VEM required for maintenance and milk production. Animal maintenance requirements are $42.4 \mathrm{VEM} /$ $\mathrm{kg}^{0.75} \cdot \mathrm{d}(1,000 \mathrm{VEM}=6.9 \mathrm{MJ}$ of net energy $)$. The VEM required for milk production is $442 \mathrm{VEM} / \mathrm{kg}$ of fat and protein-corrected milk (Van Es, 1975). In calculating the maintenance and milk energy requirements, a correction factor to scale requirements to an average cow was applied as described by Van Es (1975).

\section{Milk Yield and Composition}

Milk yield was recorded daily. Milk samples for fat, protein, lactose, and SCC analysis (ISO 9622; Qlip
NV, Zutphen, the Netherlands) were collected 4 times per week (Tuesday afternoon, Wednesday morning, Thursday afternoon, and Friday morning). In wk 2, 3, 4 , and $8 \mathrm{pp}$, an individual morning sample was stored at $-20^{\circ} \mathrm{C}$ until analysis of milk FA profile. The FA profile was obtained after milk fat extraction (mini Roese-Gottlieb method, adapted from Chouinard et al., 1997), methylation (Stefanov et al., 2010), and gas chromatography of FAME (Agilent Technologies 7890A GC System equipped with a flame ionization detector; Agilent Technologies Inc., Santa Clara, CA). Samples were injected by split injection (split ratio $=1: 50$ ). The carrier gas was hydrogen and the inlet pressure was $246.38 \mathrm{kPa}$. Fatty acid peaks were identified based on their retention times. Separation of FAME was realized with a Supelco column (SP-2560; $75 \mathrm{~m} \times 180$ $\mu \mathrm{m} \times 0.14 \mu \mathrm{m}$; Sigma-Aldrich, St. Louis, MO). The temperature program ran from a starting temperature of $70^{\circ} \mathrm{C}$ for $2 \mathrm{~min}$, which then was increased at $15^{\circ} \mathrm{C} /$ min up to $150^{\circ} \mathrm{C}$ and then increased at $1^{\circ} \mathrm{C} / \mathrm{min}$ up to $165^{\circ} \mathrm{C}$, held at $165^{\circ} \mathrm{C}$ for $12 \mathrm{~min}$, increased at $2^{\circ} \mathrm{C} / \mathrm{min}$ up to $170^{\circ} \mathrm{C}$, held at $170^{\circ} \mathrm{C}$ for $5 \mathrm{~min}$, and increased at $5^{\circ} \mathrm{C} / \mathrm{min}$ up to $215^{\circ} \mathrm{C}$, with the final temperature held for 10 min. The proportion of FAME was determined with Agilent ChemStation software (B.04.03; Agilent Technologies Inc.; as governed by United States and International copyright laws; edition 9/2010) and tridecanoic acid (C13:0; as triacylglyceride; Sigma, Bornem, Belgium) was used as internal standard. Fatty acids were expressed as grams per $100 \mathrm{~g}$ of FAME. Fatty acid peaks were identified through mixtures of methyl ester standards (BR2 and BR3, Larodan Fine Chemicals AB, Malmö, Sweden; Supelco 37, Supelco Analytical, Bellefonte, PA; PUFA-3, Matreya LLC, Pleasant Gap, PA), based on retention time. Short-chain FA were corrected for their respective theoretical relative response factors (Ackman and Sipos, 1964; Wolff et al., 1995).

\section{Statistical Analysis}

Because multiple measurements per animal cannot be regarded as independent units of observation, repeated measures ANOVA (PROC MIXED of SAS version 9.1; SAS Institute Inc., Cary, NC; Littell et al., 1996) was performed for milk production, milk composition, feed intake, EB, and body condition variables. Data were analyzed for the prepartum and postpartum data separately. Prepartum, milk production and milk composition variables were analyzed with dry period length $(0,30$, or $60 \mathrm{~d})$, week (wk -8 to $-1 \mathrm{pp}$ ), parity $(2,3$, or $>3)$ and their interaction included as fixed effects (model 1). Milk component percentages were not available prepartum for the 60 -d treatment; for these variables, the dry period contrast was 0 versus $30 \mathrm{~d}$ 
Table 1. Ingredient and calculated ${ }^{1}$ chemical composition of glucogenic, lipogenic, and lactation concentrate

\begin{tabular}{|c|c|c|c|}
\hline \multirow[b]{2}{*}{ Item } & \multicolumn{3}{|c|}{ Concentrate } \\
\hline & Glucogenic & Lipogenic & Lactation \\
\hline \multicolumn{4}{|l|}{ Ingredient $(\mathrm{g} / \mathrm{kg})$} \\
\hline Rapeseed meal & 11.29 & 17.04 & 16.41 \\
\hline Corn & 53.08 & & 28.79 \\
\hline Corn meal & & & 1.94 \\
\hline Palm kernel, expeller & & 21.26 & 21.23 \\
\hline Sugar beet pulp & 7.23 & 32.10 & \\
\hline Citrus pulp & & & 12.44 \\
\hline Wheat & 3.90 & 6.12 & 0.58 \\
\hline Soybean hulls & 0.49 & & \\
\hline Soybean meal & 8.66 & 1.69 & 3.38 \\
\hline Soybean meal, formaldehyde treated & 2.24 & 1.84 & 3.86 \\
\hline Rapeseed meal, formaldehyde treated & 3.46 & 5.94 & 1.41 \\
\hline Energizer RP10² & & 2.01 & 2.01 \\
\hline Molasses & 5.70 & 4.70 & 4.03 \\
\hline Vinasses & & 3.92 & 3.41 \\
\hline Palm oil & 0.10 & 1.19 & 0.06 \\
\hline Calcium carbonate & 1.93 & 1.09 & 0.47 \\
\hline Magnesium oxide & 0.71 & 0.45 & 0.47 \\
\hline Sodium chloride & 0.75 & 0.51 & 0.55 \\
\hline Urea & & & 0.07 \\
\hline Mineral-vitamin mixture ${ }^{3}$ & 0.23 & 0.24 & 0.32 \\
\hline \multicolumn{4}{|l|}{ Calculated chemical composition } \\
\hline DM (g/kg of product) & 873 & 879 & 878 \\
\hline $\mathrm{CP}(\mathrm{g} / \mathrm{kg}$ of $\mathrm{DM})$ & 181 & 194 & 205 \\
\hline Crude fat & 33 & 71 & 45 \\
\hline NDF & 178 & 379 & 269 \\
\hline $\mathrm{ADF}$ & 79 & 222 & 161 \\
\hline ADL & 18 & 50 & 35 \\
\hline Starch & 417 & 28 & 252 \\
\hline Sugars ${ }^{4}$ & 77 & 103 & 93 \\
\hline Ash & 79 & 90 & 67 \\
\hline $\mathrm{DVE}^{5}$ & 120 & 120 & 124 \\
\hline $\mathrm{OEB}^{6}$ & 12 & 12 & 25 \\
\hline $\mathrm{NE}^{7}(\mathrm{MJ} / \mathrm{kg}$ of $\mathrm{DM})$ & 7.7 & 7.7 & 7.6 \\
\hline
\end{tabular}

${ }^{1}$ Based on Centraal Veevoederbureau (CVB) table (CVB, 2005).

${ }^{2}$ Rumen-protected fat from palm oil (IFFCO International, Port Klang, Malaysia).

${ }^{3}$ Premix 2016 (Pre-Mervo UA Cooperatie, Utrecht, the Netherlands).

${ }^{4}$ Van Vuuren et al. (1993).

${ }^{5}$ Intestinal digestible protein (Tamminga et al., 1994).

${ }^{6}$ Degraded protein balance (Tamminga et al., 1994).

${ }^{7}$ Net energy for lactation calculated with the Dutch net energy evaluation (VEM) system (Van Es, 1975).

dry. Preliminary analysis showed that milk yield in the 60-d treatment was close to zero and, therefore, also fat- and protein-corrected milk (FPCM), lactose, fat, and protein yields were zero and were as such included in the data analysis (0 vs. 30 vs. 60 d dry). Prepartum, feed intake and EB variables were analyzed with dry period length $(0,30$, or $60 \mathrm{~d}$ ), week (wk -8 to -1 $\mathrm{pp})$, parity $(2,3$, or $>3)$ and the relevant interaction terms included in the model as fixed effects (model 2). Postpartum, milk production, milk composition, milk fat composition, feed intake, and EB variables were analyzed with dry period length $(0,30$, or $60 \mathrm{~d})$, ration (glucogenic or lipogenic), week (wk 1 to $14 \mathrm{pp}$ ), parity $(2,3$, or $>3)$, and the relevant interaction terms included in the model as fixed effects (model 3). For all models, cow was considered as the repeated effect. All cows were included in the analyses for milk production, milk composition, $\mathrm{EB}$, and body condition variables; a selection of cows was included in the analysis for milk fat composition $(\mathrm{n}=82)$. A first-order autoregressive structure $[\mathrm{AR}(1)]$ was the best fit and was used to account for within-cow variation. Model assumptions were evaluated by examining the distribution of residuals. For comparison of dry period lengths, $P$-values are presented after a Bonferroni adjustment. Values are presented as least squares means with their standard error of the mean, unless otherwise stated.

\section{RESULTS}

Actual days dry were similar to planned days dry having $61 \pm 1,30 \pm 1$, and $2 \pm 1 \mathrm{~d}$ dry (means $\pm \mathrm{SEM}$ ) 
Table 2. Ingredient and calculated chemical composition ( $\mathrm{g} / \mathrm{kg}$ of $\mathrm{DM}$, unless otherwise stated) of prepartum and postpartum rations ${ }^{1}$

\begin{tabular}{|c|c|c|c|c|}
\hline \multirow[b]{2}{*}{ Composition } & \multicolumn{2}{|c|}{ Prepartum ration } & \multicolumn{2}{|c|}{ Postpartum ration } \\
\hline & Dry & Lactating & Glucogenic & Lipogenic \\
\hline \multicolumn{5}{|l|}{ Ingredient } \\
\hline Grass silage & 391 & 484 & 338 & 338 \\
\hline Corn silage & 245 & 321 & 227 & 227 \\
\hline Soybean meal & 38 & 68 & 46 & 46 \\
\hline Rapeseed meal & 79 & 52 & 36 & 36 \\
\hline Rapeseed straw & 2 & 1 & 10 & 10 \\
\hline Wheat straw & 245 & 13 & 5 & 5 \\
\hline Concentrate & 0 & 56 & 338 & 338 \\
\hline \multicolumn{5}{|l|}{ Chemical composition } \\
\hline $\mathrm{DM}$ (g/kg of product) & 532 & 453 & 561 & 566 \\
\hline $\mathrm{CP}$ & 116 & 159 & 167 & 169 \\
\hline Crude fat & 26 & 31 & 31 & 37 \\
\hline NDF & 527 & 384 & 318 & 389 \\
\hline $\mathrm{ADF}$ & 326 & 229 & 182 & 224 \\
\hline Starch & 65 & 117 & 215 & 106 \\
\hline Sugars $^{2}$ & 67 & 80 & 82 & 85 \\
\hline Ash & 74 & 76 & 76 & 80 \\
\hline $\mathrm{DVE}^{3}$ & 47 & 80 & 87 & 84 \\
\hline $\mathrm{OEB}^{4}$ & 10 & 21 & 17 & 17 \\
\hline $\mathrm{NE}^{5}(\mathrm{MJ} / \mathrm{kg}$ of $\mathrm{DM})$ & 5.26 & 6.48 & 6.55 & 6.52 \\
\hline
\end{tabular}

for the conventional dry period, short dry period, and no dry period, respectively.

\section{Milk Production}

Precalving. Shortening or omitting the dry period resulted in an extra daily milk production of $7.7 \pm 0.5$ and $13.8 \pm 0.5 \mathrm{~kg} / \mathrm{d}$ in the last 8 wk before calving (Table 3). Total milk production in the last $8 \mathrm{wk}$ before calving was $429 \pm 30 \mathrm{~kg}$ for cows with a short dry period and $774 \pm 27 \mathrm{~kg}$ for cows without a dry period. Total FPCM was $453 \pm 30 \mathrm{~kg}$ for cows with a short dry period and $894 \pm 29 \mathrm{~kg}$ for cows without a dry period. Furthermore, prepartum daily milk production tended $(P<0.10)$ to be greater for young cows (parity 1) compared with older cows (parity $>1$ ). Daily milk production of young cows with a short dry period was $9.0 \pm 1.4 \mathrm{~kg} / \mathrm{d}$ and without a dry period was $15.1 \pm 1.4$ $\mathrm{kg} / \mathrm{d}$, compared with $8.7 \pm 1.0$ and $12.0 \pm 1.0 \mathrm{~kg} / \mathrm{d}$ for older cows with a short or no dry period, respectively.

Postcalving. Shortening or omitting the dry period reduced total milk and FPCM yields, lactose percentage, and lactose, fat, and protein yields $(P<0.05)$, but omitting the dry period increased milk fat and protein percentage and milk SCC, compared with a conventional dry period of $60 \mathrm{~d}$ (Table 4). Both total milk production and FPCM yield in the first 14 wk postcalving were less $(P<0.01)$ for cows with a short (milk: 3,795 $\pm 66 \mathrm{~kg}$; FPCM: $3,999 \pm 56 \mathrm{~kg}$ ) or no dry period (milk: $3,192 \pm 103 \mathrm{~kg}$; FPCM: 3,486 $\pm 99 \mathrm{~kg}$ ), compared with cows with a conventional dry period (milk: 4,238 \pm $58 \mathrm{~kg}$; FPCM: 4,333 $\pm 54 \mathrm{~kg}$ ). Milk yield (Figure 1), FPCM yield, and lactose and protein percentages were affected by a dry period length $\times$ week interaction. Furthermore, except milk lactose percentage, milk yield and composition variables were affected by a dry period length $\times$ parity interaction. Young cows (parity 2 postcalving) had a greater reduction in milk yield when the dry period length was omitted (28.6 vs. 37.9 vs. $41.8 \pm$ $1.1 \mathrm{~kg} / \mathrm{d}$ for no vs. short vs. conventional dry period, respectively), than older cows (34.8 vs. 39.2 vs. $44.1 \pm$ $0.8 \mathrm{~kg} / \mathrm{d}$ for no vs. short vs. conventional dry period, respectively).

Dietary energy source did not affect milk yield, but cows fed the glucogenic ration tended to have a greater milk lactose percentage and lower milk fat percentage, compared with cows fed the lipogenic ration.

\section{$E B$}

Eight weeks precalving, BCS $(3.1 \pm 0.11)$ and BW $(701 \pm 5 \mathrm{~kg})$ did not differ among dry period lengths. Precalving, DMI, and energy intake were greater for cows without dry period, whereas the EB was greater 
Table 3. Milk production and milk composition precalving ${ }^{1}$ of dairy cows provided a dry period of 0, 30, or $60 \mathrm{~d}$ (LSM \pm SEM)

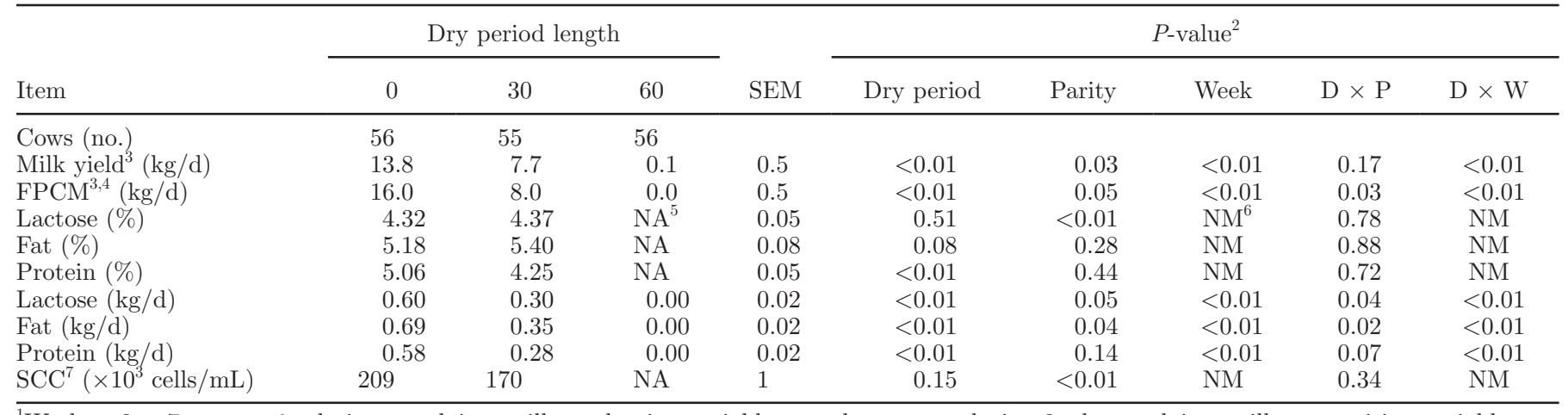

${ }^{1}$ Weeks $-8,-7, \ldots,-1$ relative to calving; milk production variables are the average during 8 wk precalving; milk composition variables are the average milk composition when lactating.

${ }^{2} \mathrm{D}=$ dry period; $\mathrm{P}=$ parity; $\mathrm{W}=$ week.

${ }^{3}$ Average daily production over last 8 wk before calving.

${ }^{4}$ Fat- and protein-corrected milk.

${ }^{5} \mathrm{NA}=$ not available.

${ }^{6} \mathrm{NM}=$ not included in the model.

${ }^{7} P$-values are based on the natural logarithm of SCC.

for cows with a conventional dry period of $60 \mathrm{~d}$ (Table $5)$. In the last week before calving, BW of cows with a short dry period was lower, compared with cows with a conventional dry period $(739 \pm 9$ vs. $770 \pm 11 \mathrm{~kg} ; P$ $=0.03)$.

Postcalving, DMI did not differ between dry period lengths or rations, but energy intake was lower for cows without a dry period (Table 6). Energy balance (Figure 2 ), BW, and BCS were greater for cows without a dry period compared with cows with a short or conventional dry period. Also a short dry period improved the EB and BCS compared with a conventional dry period.

Energy balance was affected by a dry period length $x$ parity interaction precalving and tended to be affected by a dry period length $\times$ parity interaction postcalving (Figure 3). Precalving, young cows (parity 2) had a lower EB when the dry period was shortened or omitted $\left(18\right.$ vs. 62 vs. $146 \pm 14 \mathrm{~kJ} / \mathrm{kg}^{0.75} \cdot \mathrm{d}$ for 0 vs. 30 vs. $60 \mathrm{~d}$ dry, respectively). Precalving, older cows had a similar EB for 0 or $30 \mathrm{~d}$ dry, which was both lower than the EB of cows with a $60-\mathrm{d}$ dry period $(P<0.01 ; 104$ vs. 81 vs. $168 \pm 10 \mathrm{~kJ} / \mathrm{kg}^{0.75} \cdot \mathrm{d}$ for 0 vs. 30 vs. $60 \mathrm{~d}$ dry, respectively). Postcalving, young cows had a similar EB for 30 or $60 \mathrm{~d}$ dry, which was both lower than the EB of cows with a 0 -d dry period $(P<0.01 ; 120$ vs. -47 vs. -93 $\pm 23 \mathrm{~kJ} / \mathrm{kg}^{0.75}$.d for 0 vs. 30 vs. $60 \mathrm{~d}$ dry, respectively). Postcalving, older cows had an improved EB when the dry period was shortened or omitted, compared with a dry period of $60 \mathrm{~d}(-2$ vs. -69 vs. $-150 \pm 17 \mathrm{~kJ} /$ $\mathrm{kg}^{0.75} \cdot \mathrm{d}$ for 0 vs. 30 vs. $60 \mathrm{~d}$ dry, respectively). Dietary energy source did not affect DMI, energy intake, BW, and BCS, but cows fed the glucogenic ration had an improved EB in early lactation, compared with cows fed the lipogenic ration. Moreover, effects of dry period length and dietary energy source on EB in early lactation were independent of each other.

\section{Milk Fat Composition}

Shortening and omitting the dry period increased the proportion of short- and medium-chain FA in milk fat and omitting the dry period decreased the proportion of long-chain FA in milk fat $(P<0.05$; Table 7$)$. Of the short-chain FA in milk fat, omitting and shortening the dry period increased C10:0 and C12:0 $(P<0.01)$, but reduced $\mathrm{C} 4: 0(P<0.01)$, compared with milk of cows with a conventional dry period. Of the medium-chain FA in milk fat, omitting and shortening the dry period increased C14:0 $(P<0.01)$ and $\mathrm{C} 14: 1(P<0.01)$, compared with milk of cows with a conventional dry period. In addition, omitting the dry period increased C16:0 $(P$ $=0.02$ ), compared with a conventional dry period. Of the long-chain FA in milk fat, omitting the dry period decreased cis-9 C17:1 $(P<0.05)$, C18:0 $(P<0.01)$, and cis-9 C18:1 $(P<0.01)$ and increased C18:2n-6 $(P$ $=0.03)$, compared with milk of cows with a short or conventional dry period.

A glucogenic ration tended $(P<0.10)$ to increase the proportion of short- and medium-chain FA in milk fat, compared with a lipogenic ration. Of the shortand medium-chain FA in milk fat, the glucogenic ration increased C6:0, C8:0, C10:0, C14:0, and C15:0 and decreased C16:0, compared with a more lipogenic ration. Of the long-chain FA, a more glucogenic ration 
increased C18:2n-6 and C18:3n-3 in milk fat, compared with a more lipogenic ration.

\section{DISCUSSION}

The current study demonstrates that both reducing dry period length and feeding a more glucogenic ration, compared with a more lipogenic ration, can improve the EB of dairy cows in early lactation. Also earlier studies detected an improvement in EB in early lactation after a dry period of $4 \mathrm{wk}$ (Rastani et al., 2005) or no dry period (Rastani et al., 2005; de Feu et al., 2009), compared with a dry period of 8 wk. Furthermore, some studies reported an improvement in BCS postpartum after a short (Gulay et al., 2003; Pezeshki et al., 2008) or no dry period (de Feu et al., 2009; Schlamberger et al., 2010), but not all (Andersen et al., 2005; Pezeshki et al., 2007). Also, in the current study, BCS postpartum was greater for cows without or a short dry period, compared with a conventional dry period of $60 \mathrm{~d}$.

In the past, it has been shown that the reduction in milk production after a short dry period is larger for young cows (second parity), compared with older cows (Pezeshki et al., 2007). Moreover, both Annen et al. (2004) and Santschi et al.(2011a) reported a reduction in milk yield after shortening or omitting the dry period for young cows (parity 2), but not for older cows. In the current study, a short dry period reduced milk production postcalving for older cows, but not for young cows, compared with a conventional dry period. Omission of the dry period reduced milk production postcalving for both young and older cows, compared with a conventional dry period. In addition, to our knowledge, this is the first study that reports not only a parity $\times$ dry period length interaction on milk production, but also on $\mathrm{EB}$, both in the last $8 \mathrm{wk}$ before calving, and in the first 14 wk after calving. Although omission of the dry period can further improve the EB postcalving compared with a short dry period for second-parity cows, EB postcalving of older cows without a dry period or a short dry period is similar to the EB in older cows with a short dry period.

Earlier, we hypothesized that a negative EB in early lactation is related to an unbalance in availability of lipogenic and glucogenic nutrients (van Knegsel et al., 2005 ) and showed that an increase in glucogenic nutrients improved the EB (van Knegsel et al., 2007a) and reduced the risk for metabolic disorders (van Knegsel et al., 2007b). In the current study, the contrast in EB between the glucogenic and lipogenic ration $(34 \mathrm{~kJ} /$ $\left.\mathrm{kg}^{0.75} \cdot \mathrm{d}\right)$ was less compared with earlier work $[78 \mathrm{~kJ} /$ $\mathrm{kg}^{0.75} \cdot \mathrm{d}$ (van Knegsel et al., 2007a) and $56 \mathrm{~kJ} / \mathrm{kg}^{0.75} \cdot \mathrm{d}$ (van Knegsel et al., 2007b)]. This difference between studies may be due to a reduced contrast in starch and 
Table 5. Dry matter intake and energy balance of dairy cows precalving ${ }^{1}$ provided a dry period of 0, 30, or $60 \mathrm{~d}$ (LSM \pm SEM)

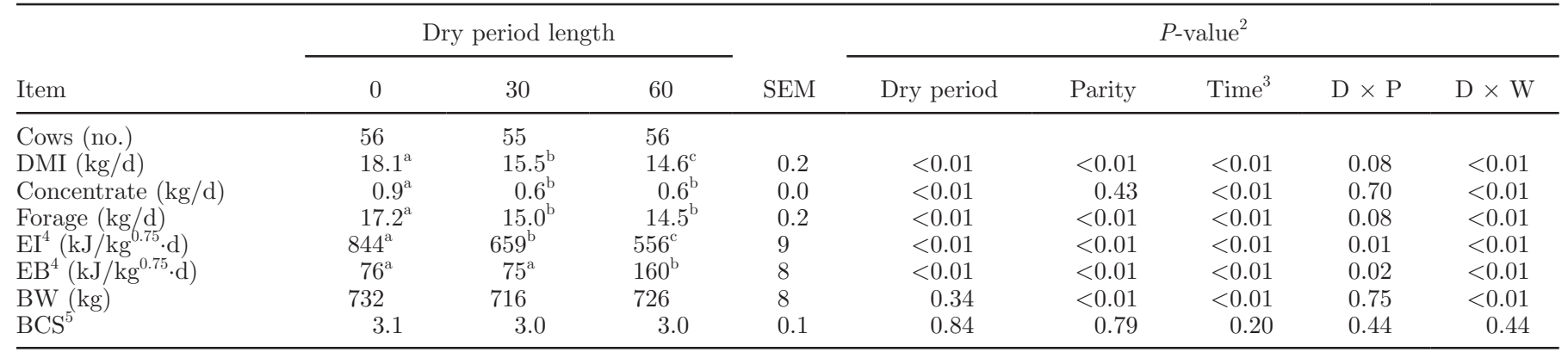

${ }^{\mathrm{a}-\mathrm{c}}$ Values within dry period length within a row with different superscript letters differ $(P<0.05)$.

${ }^{1}$ Weeks $-8,-7, \ldots,-1$ relative to calving.

${ }^{2} \mathrm{D}=$ dry period; $\mathrm{P}=$ parity; $\mathrm{W}=$ week.

${ }^{3}$ Week relative to calving [for DMI, energy intake (EI), energy balance (EB), and BW] or month relative to calving (for BCS).

${ }^{4}$ Calculated with the Dutch net energy evaluation (VEM) system (Van Es, 1975).

${ }^{5}$ Body condition score on a scale of 1 to 5 .

fat content between experimental concentrates and a reduced contribution of experimental concentrates to the ration.

In the current study, both the glucogenic ration and the reduced dry period length improved the EB by reducing the amount of energy partitioned to milk. A glucogenic ration, compared with a more lipogenic ration, tended to reduce milk fat percentage without affecting milk protein or total amount of milk produced.
Reducing the dry period length reduced total milk yield as well as the total amount of lactose, fat, and protein produced per cow per day. Earlier, the improved EB by a glucogenic ration was related specifically to a reduction of long-chain FA in milk fat (van Knegsel et al., 2007a). This does not correspond with the current study, as dietary energy source did not affect the proportion of long-chain FA in milk, but increased the proportion of short-chain FA in milk fat and tended to

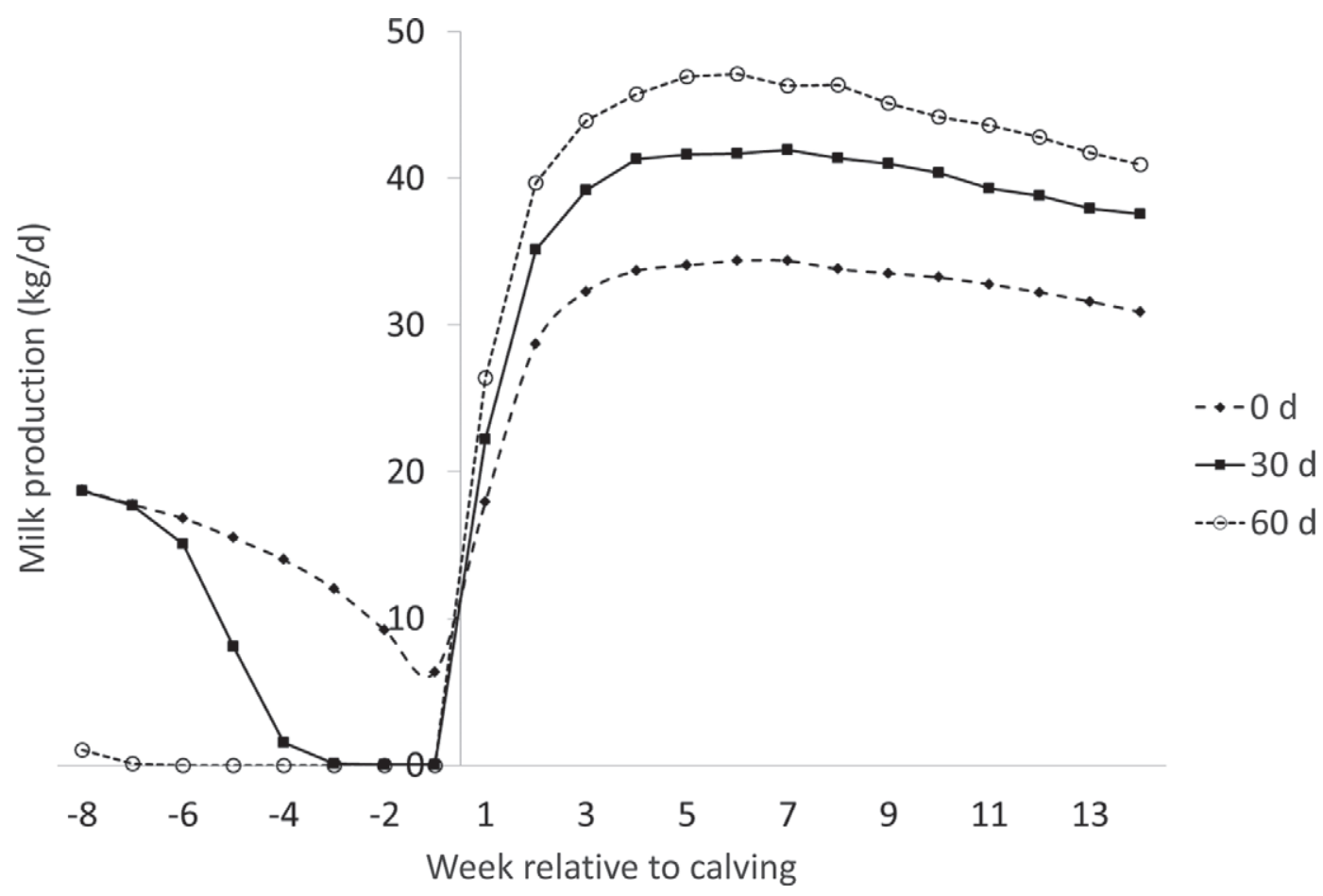

Figure 1. Milk production of dairy cows with different dry period lengths (0,30, or $60 \mathrm{~d}$ dry). Values represent LSM per dry period length per week. 
reduce the proportion of medium-chain FA in milk fat. Discrepancies between studies in milk fat composition could be due to differences between studies in ration effects on EB and contrasts between studies in dietary fat content as discussed above.

Reports on additional milk precalving due to a shorter or no dry period vary from 422 to $459 \mathrm{~kg}$ for a short dry period of approximately 4 wk (Annen et al., 2004; Rastani et al., 2005) and from 438 to $1,186 \mathrm{~kg}$ for no dry period (Annen et al., 2004; Andersen et al., 2005; Rastani et al., 2005; Schlamberger et al., 2010), which is in line with the current study. Extra milk precalving depends on milk yield potential, lactation persistency, and ration composition, which could explain large differences between studies, between parities, or individual cows.

In the current study, the dry period length treatment had implications for the precalving ration. Dry cows received a dry cow ration precalving and lactating cows a lactation ration precalving, which is in line with earlier studies (Rastani et al., 2005; de Feu et al., 2009; Schlamberger et al., 2010). This implies that a dry period treatment does not only concern length of the dry period, but adjustment of precalving strategy. Grummer and Rastani (2004) suggested that when the dry period is shortened sufficiently, continuous feeding of a high-energy ration throughout the entire gestation and lactation would be possible without the risk of overconditioned cows in the prepartum period. Later they reported, however, a greater EB prepartum for cows with a short dry period ( $28 \mathrm{~d}$ ) and fed a high-energy ration, compared with cows with a 56-d dry period and fed a low-energy ration and cows without dry period and fed a high-energy ration (Rastani et al., 2005). In the current study, cows without dry period were fed the lactation ration (high energy) continuously, but cows with a short dry period were fed a dry cow ration (low energy) in the last 4 wk before calving. In this study, continuous milking (no dry period) was related to a greater DMI and energy intake prepartum compared with cows with a short or conventional dry period. Nevertheless, precalving EB was lower for cows without a dry period and cows with a short dry period, compared with cows with a conventional dry period. Both studies indicate that continuous milking can reduce the risk of fattening of dairy cows in the prepartum period when cows are fed a high-energy or lactating ration. In addition, combined results of both studies suggest that also a short dry period has the potential to reduce the risk of fattening in the prepartum period provided that cows are fed a low-energy ration during the nonlactating period and not a high-energy ration.

A dry period of 6 to 8 wk has been shown to be optimal to maximize milk yield in the next lactation 


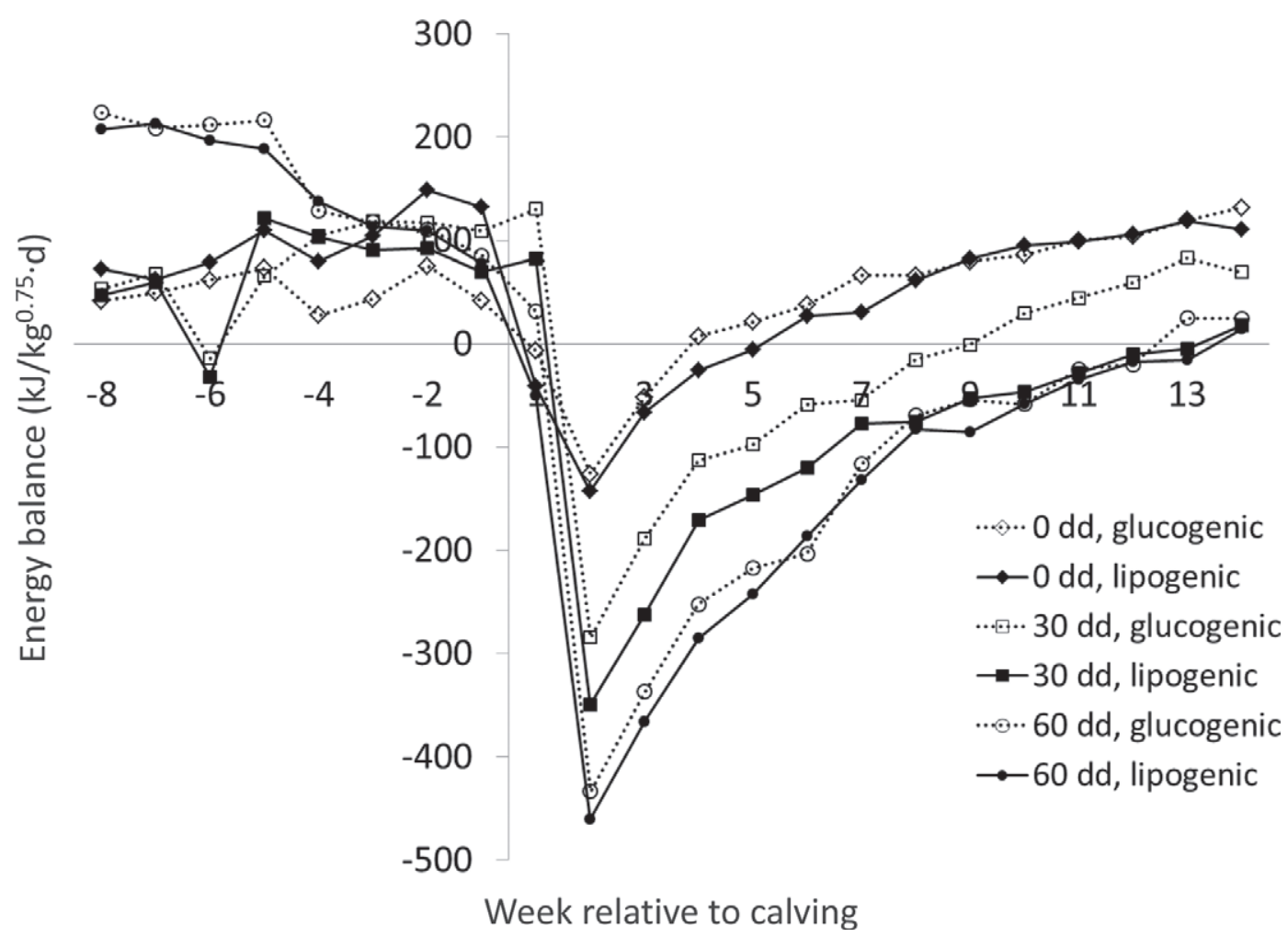

Figure 2. Energy balance of dairy cows with different dry period lengths $[0,30$, or $60 \mathrm{~d}$ dry (dd)] and fed either a glucogenic or a lipogenic ration in early lactation. Values represent LSM per treatment per week.

(e.g., Kuhn et al., 2005), and shorter dry periods cost milk. These milk yield losses have been explained by a reduced renewal of mammary epithelial cells in the last weeks before parturition when cows are continuously milked, compared with cows with a dry period of 8 wk (Capuco et al., 1997). Estimations for milk yield loss of continuous milking vary from 20 (Rastani et al., 2005 ) to $22 \%$ (Andersen et al., 2005) when cows are monitored for a limited period in lactation (70 or 35 DIM, respectively), but seem to be less when cows are monitored for a longer period postcalving [e.g., 9 (Annen et al., 2004) or $16 \%$ (Schlamberger et al., 2010) for 119 and 305 DIM, respectively]. For a short dry period of approximately $4 \mathrm{wk}$, milk yield losses vary from 2 to 11\% (Annen et al., 2004; Rastani et al., 2005). Taking into account also the additional milk yield precalving, milk losses were reduced to $6 \%$ in the study of Schlamberger et al. (2010). In studies that monitor cows for a limited period in the subsequent lactation, the loss in milk yield postcalving was completely compensated for by the additional milk precalving (Annen et al., 2004; Andersen et al., 2005; Rastani et al., 2005). In the current study, the additional milk precalving could not compensate for the loss resulting from shortening ( $-1 \% ; 4,224$ vs. $4,238 \mathrm{~kg}$ of milk) or omitting the dry period $(-6 \% ; 3,966$ vs. $4,238 \mathrm{~kg}$ of milk). Especially young cows (parity 2) had a great total loss in milk yield $(-11 \% ; 3,680$ vs. $4,070 \mathrm{~kg}$ of milk) when the dry period was omitted, compared with older cows $(-5 \% ; 4,142$ vs. $4,344 \mathrm{~kg}$ of milk). In the current study, however, greater concentrations of milk components completely compensated for the loss of milk volume for older cows, but not for young cows. Young cows without a dry period had less FPCM, compared with a conventional dry period $(-2 \% ; 4105$ vs. $4180 \mathrm{~kg}$ of FPCM). Older cows had a greater FPCM yield without a dry period, compared with a conventional dry period $(+4 \% ; 4,082$ vs. $3,915 \mathrm{~kg}$ of FPCM). This confirms the hypothesis that shortening or omitting the dry period shifts milk production from the period postcalving to the period before calving (Grummer et al., 2010) and herewith can repartition energy from milk to body reserves, which results in an improvement of the EB in early lactation. Data on total lactation milk production with different dry period lengths are limited. As milk production differences between different dry period lengths in the current study persist through wk 14 in lactation, it can be expected that milk yield losses after a short or without a dry period increase when the monitoring period is expanded to the complete lactation.

The dry period has been widely used to treat cows suffering from subclinical IMI or high SCC with antibi- 
a)
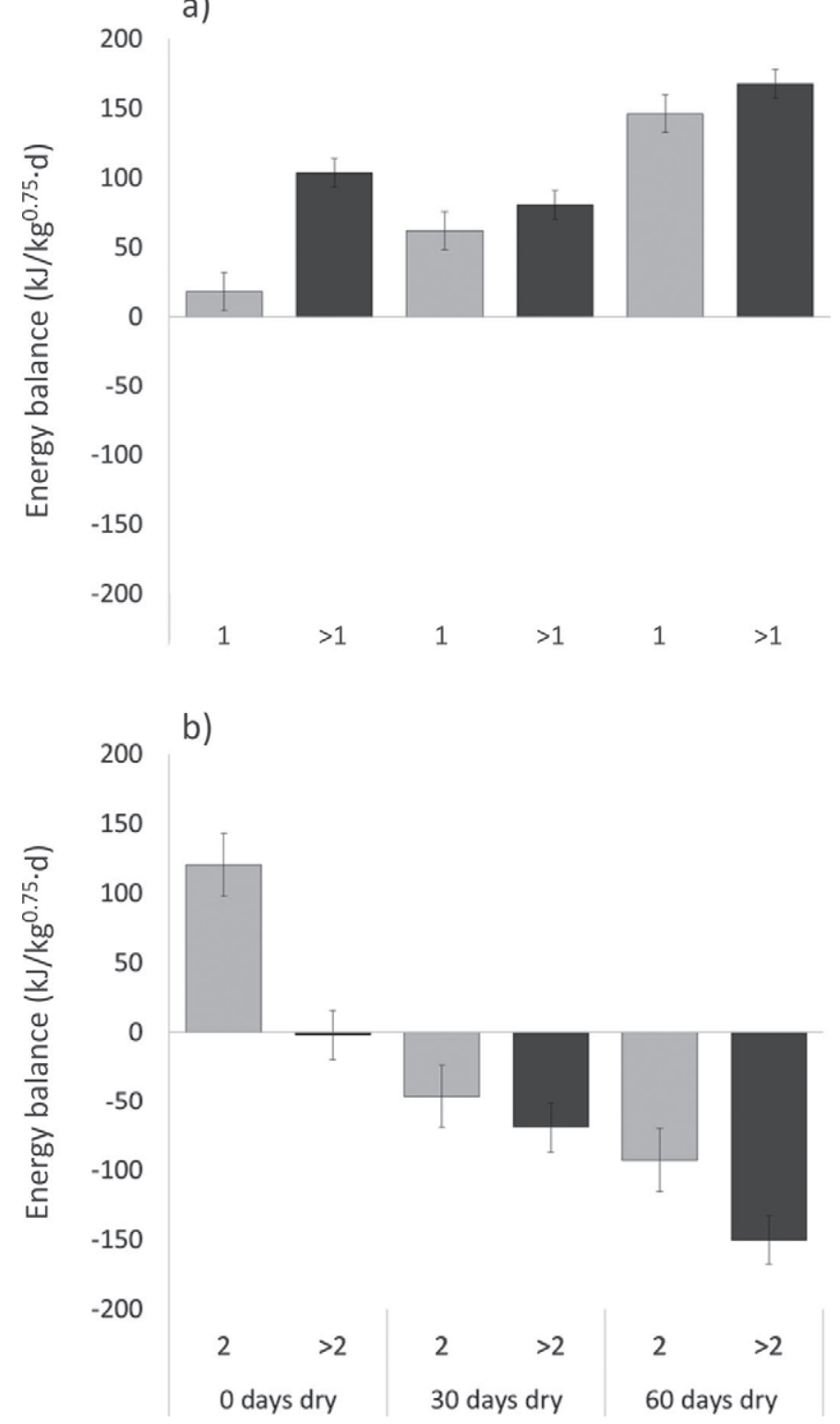

Figure 3. (a) Energy balance precalving (wk -8 to -1) of young (parity 1 ) and older (parity $>1$ ) dairy cows with different dry period lengths. (b) Energy balance postcalving (wk 1 to 14) of young (parity 2 ) and older (parity $>2$ ) dairy cows with different dry period lengths. Values represent LSM $( \pm$ SEM $)$ per treatment per parity class.

otics (Neave et al., 1966; Bradley et al., 2011). Recently, however, Collier et al. (2012) discussed how the dry period can also be a risky period with respect to the development of new IMI. Especially in the first days after drying-off and during the last $3 \mathrm{wk}$ before calving, the risk for a new IMI seems to be increased (Bradley and Green, 2004). Recent studies report contrasting effects of omission or shortening the dry period on mastitis incidence (Pezeshki et al., 2008; Schlamberger et al., 2010; Santschi et al., 2011a). In line with this, some studies reported an increase in SCC in milk after a short or no dry period (Annen et al., 2004; Klusmeyer et al., 2009), but others did not observe an effect on SCC (Rastani et al., 2005; Watters et al., 2008). In the current study, omission of the dry period, but not shortening of the dry period, increased SCC compared with a dry period of $60 \mathrm{~d}$. Moreover, it was suggested that an increase in SCC due to omission of the dry period can be attributed to the reduced milk yield and a reduced diluting effect (Steeneveld et al., 2013). This might imply that a major part of the effect of dry period length on SCC is determined by the effect of dry period length on milk production. In addition, also omission of preventive of antibiotic use for cows without a dry period might contribute to observed dry period length effects on SCC. In the current study, all cows without a dry period were not treated with preventive antibiotics, whereas cows with a short or conventional dry period were treated with an intramammary antibiotic at the start of the dry period.

Besides reduced milk yield and increased SCC, a reduced colostrum quality, as indicated by lower IgG content (Annen et al., 2004; Klusmeyer et al., 2009), has been reported as a disadvantage of omission of the dry period, but not of a short dry period (Annen et al., 2004; Klusmeyer et al., 2009).

Eventually, a decision to shorten or eliminate the dry period will be determined by the profitability of decreasing days dry. Profitability of decreasing days dry will depend on the extra milk precalving, lactation persistency, reduction in milk yield in the subsequent lactation, increase in milk components, reduction in veterinary and labor costs associated with the occurrence of disease or fertility problems, and effects on cow longevity. Recently, Santschi et al., (2011b) suggested that a short dry period, compared with a conventional dry period, would be beneficial for average dairy herds in eastern Canada. To our knowledge an economic evaluation of a dairy management system without a dry period is not available yet. Therefore, long-term studies using a randomized controlled experimental setup with a multidisciplinary approach, including not only milk production, but also metabolism, health, welfare, and economic aspects, will be essential to support the farmers' decision to shorten or eliminate the dry period.

\section{CONCLUSIONS}

The results of the current study indicate that a short dry period $(30 \mathrm{~d})$, no dry period, and a glucogenic ration can improve the EB of dairy cows in early lactation by reducing the amount of energy partitioned to milk. A reduced dry period (30 or $0 \mathrm{~d}$ ), compared with a conventional dry period of $60 \mathrm{~d}$, improved the $\mathrm{EB}$ 
Table 7. Milk FA composition ( $\mathrm{g} / 100 \mathrm{~g}$ of FA) for dairy cows in early lactation ${ }^{1}$ after a 0-, 30-, or 60-d dry period and fed either a glucogenic (G) or a lipogenic (L) ration (LSM \pm SEM)

\begin{tabular}{|c|c|c|c|c|c|c|c|c|c|c|c|c|c|c|c|}
\hline \multirow[b]{2}{*}{ Item } & \multicolumn{3}{|c|}{ Dry period length } & \multirow[b]{2}{*}{ SEM } & \multicolumn{2}{|c|}{ Ration } & \multirow[b]{2}{*}{ SEM } & \multicolumn{8}{|c|}{$P$-value ${ }^{2}$} \\
\hline & 0 & 30 & 60 & & G & $\mathrm{L}$ & & Dry period & Ration & Parity & Time $^{3}$ & $\mathrm{D} \times \mathrm{R}$ & $\mathrm{D} \times \mathrm{P}$ & $\mathrm{D} \times \mathrm{T}$ & $\mathrm{R} \times \mathrm{P}$ \\
\hline Cows (no.) & 28 & 26 & 28 & & 41 & 41 & & & & & & & & & \\
\hline $4: 0$ & $3.30^{\mathrm{a}}$ & $3.52^{\mathrm{b}}$ & $3.57^{\mathrm{b}}$ & 0.05 & 3.37 & 3.55 & 0.04 & $<0.01$ & $<0.01$ & 0.22 & $<0.01$ & 0.47 & 0.38 & 0.40 & 0.05 \\
\hline 6:0 & $2.20^{\mathrm{a}}$ & $2.30^{\mathrm{b}}$ & $2.22^{\mathrm{ab}}$ & 0.03 & 2.28 & 2.20 & 0.02 & 0.06 & 0.02 & 0.06 & 0.53 & 0.43 & 0.39 & 0.06 & 0.33 \\
\hline 8:0 & $1.35^{\mathrm{ab}}$ & $1.40^{\mathrm{a}}$ & $1.29^{\mathrm{b}}$ & 0.03 & 1.42 & 1.28 & 0.02 & 0.02 & $<0.01$ & 0.09 & $<0.01$ & 0.58 & 0.35 & 0.05 & 0.89 \\
\hline 10:0 & $3.15^{\mathrm{a}}$ & $3.14^{\mathrm{a}}$ & $2.80^{\mathrm{b}}$ & 0.07 & 3.27 & 2.79 & 0.06 & $<0.01$ & $<0.01$ & 0.03 & $<0.01$ & 0.85 & 0.28 & 0.01 & 0.88 \\
\hline $12: 0$ & $4.29^{\mathrm{a}}$ & $4.16^{\mathrm{a}}$ & $3.64^{\mathrm{b}}$ & 0.10 & 4.03 & 4.03 & 0.08 & $<0.01$ & 0.98 & $<0.01$ & $<0.01$ & 0.92 & 0.28 & $<0.01$ & 0.83 \\
\hline Total short-chain $\mathrm{FA}^{4}$ & $14.88^{\mathrm{a}}$ & $15.28^{\mathrm{a}}$ & $13.98^{\mathrm{b}}$ & 0.29 & 15.05 & 14.38 & 0.24 & $<0.01$ & 0.05 & 0.06 & $<0.01$ & 0.71 & 0.36 & 0.02 & 0.82 \\
\hline $14: 0$ & $11.51^{\mathrm{a}}$ & $11.38^{\mathrm{a}}$ & $10.63^{\mathrm{b}}$ & 0.18 & 11.46 & 10.89 & 0.14 & $<0.01$ & $<0.01$ & 0.05 & $<0.01$ & 0.25 & 0.64 & $<0.01$ & 0.66 \\
\hline $14: 1$ & $1.05^{\mathrm{a}}$ & $0.98^{\mathrm{a}}$ & $0.83^{\mathrm{b}}$ & 0.04 & 0.99 & 0.92 & 0.03 & $<0.01$ & 0.12 & 0.03 & $<0.01$ & 0.77 & 0.35 & 0.06 & 0.33 \\
\hline $15: 0$ & 1.64 & 1.71 & 1.51 & 0.09 & 1.73 & 1.52 & 0.07 & 0.26 & 0.04 & 0.40 & $<0.01$ & 0.99 & 0.24 & 0.14 & 0.75 \\
\hline 16:0 & $32.77^{\mathrm{a}}$ & $32.29^{\mathrm{ab}}$ & $31.52^{\mathrm{b}}$ & 0.38 & 31.09 & 33.29 & 0.31 & 0.06 & $<0.01$ & 0.08 & $<0.01$ & 0.22 & 0.22 & 0.14 & 0.04 \\
\hline cis-9 16:1 & 1.72 & 1.72 & 1.74 & 0.05 & 1.73 & 1.72 & 0.04 & 0.96 & 0.96 & 0.44 & $<0.01$ & 0.45 & 0.35 & 0.28 & 0.78 \\
\hline Total medium-chain $\mathrm{FA}^{5}$ & $49.21^{\mathrm{a}}$ & $48.80^{\mathrm{a}}$ & $46.68^{\mathrm{b}}$ & 0.56 & 47.60 & 48.86 & 0.45 & $<0.01$ & 0.05 & 0.03 & $<0.01$ & 0.24 & 0.45 & $<0.01$ & 0.34 \\
\hline $17: 0$ & 1.36 & 1.57 & 1.53 & 0.07 & 1.54 & 1.44 & 0.06 & 0.13 & 0.25 & 0.55 & 0.01 & 0.65 & 0.52 & 0.42 & 0.67 \\
\hline cis-9 17:1 & $0.19^{\mathrm{a}}$ & $0.28^{\mathrm{b}}$ & $0.26^{\mathrm{b}}$ & 0.02 & 0.25 & 0.23 & 0.02 & 0.03 & 0.42 & 0.68 & $<0.01$ & 0.72 & 0.54 & 0.27 & 0.72 \\
\hline $18: 0$ & $8.98^{\mathrm{a}}$ & $9.70^{\mathrm{b}}$ & $10.03^{\mathrm{b}}$ & 0.17 & 9.73 & 9.42 & 0.14 & $<0.01$ & 0.13 & $<0.01$ & $<0.01$ & 0.71 & 0.73 & 0.23 & 0.71 \\
\hline cis-9 18:1 & $18.04^{\mathrm{a}}$ & $18.91^{\mathrm{a}}$ & $20.42^{\mathrm{b}}$ & 0.38 & 19.04 & 19.21 & 0.30 & $<0.01$ & 0.68 & 0.28 & $<0.01$ & 0.38 & 0.54 & $<0.01$ & 0.19 \\
\hline $18: 2 n-6$ & $1.41^{\mathrm{a}}$ & $1.32^{\mathrm{ab}}$ & $1.18^{\mathrm{b}}$ & 0.06 & 1.47 & 1.13 & 0.05 & 0.03 & $<0.01$ & 0.88 & 0.58 & $<0.01$ & $<0.01$ & 0.84 & 0.64 \\
\hline $18: 3 n-3$ & 0.43 & 0.42 & 0.37 & 0.03 & 0.45 & 0.37 & 0.02 & 0.33 & 0.02 & 0.62 & 0.78 & 0.06 & 0.33 & 0.82 & 0.35 \\
\hline Total long-chain $\mathrm{FA}^{6}$ & $33.18^{\mathrm{a}}$ & $35.50^{\mathrm{b}}$ & $36.58^{\mathrm{b}}$ & 0.66 & 35.61 & 34.57 & 0.53 & $<0.01$ & 0.17 & 0.04 & $<0.01$ & 0.23 & 0.57 & 0.03 & 0.24 \\
\hline
\end{tabular}

${ }^{\mathrm{a}, \mathrm{b}}$ Values within dry period length within a row with different superscript letters differ $(P<0.05)$.

${ }^{1}$ Weeks $2,3,4$, and 8 relative to calving.

${ }^{2} \mathrm{D}=$ dry period; $\mathrm{R}=$ ration; $\mathrm{P}=$ parity; $\mathrm{T}=$ time.

${ }^{3}$ Week in lactation.

${ }^{4}$ Total short-chain FA include low-abundant FA: 7:0, 9:0, 10:1, 11:0, and 12:1.

${ }^{5}$ Total medium-chain FA include low-abundant FA: trans-9 16:1, cis-11 16:1, cis-13 16:1, and trans-6,trans-7,trans-8 16:1.

${ }^{6}$ Total long-chain FA include low-abundant FA: trans-6 18:1, trans-7 C18:1, trans-8 C18:1, trans-9 18:1, trans-10 18:1, trans-11 18:1, cis-12 18:1, cis-13 18:1, cis-14 18:1, cis-15 18:1, cis-9,trans-11 18:2, 20:1, 20:3, 20:4, 20:5, and 22:0. 
by reducing the production of milk, lactose, fat, and protein. A glucogenic ration, compared with a lipogenic ration, improved the $\mathrm{EB}$ by a reduction in milk fat content. No effects on DMI were found. The reduction in milk yield after a short or no dry period was accompanied by a considerable additional milk yield in the preceding lactation. So, shortening and omitting the dry period shifts milk yield from the postcalving to the precalving period; this results in an improvement in the EB in early lactation. An increased energy status after a short dry period can be further improved by feeding a more glucogenic ration in early lactation.

\section{ACKNOWLEDGMENTS}

The authors thank the Dutch Dairy Board (PZ; Zoetermeer, the Netherlands), Product Board Animal Feed (PDV; Zoetermeer, the Netherlands), and CRV BV (Arnhem, the Netherlands) for financing the experiment. Author S. Jorjong received a Royal Thai Government Scholarship and her research was supported by an International Co-ordinated Action of the Fund for Scientific Research-Flanders (Belgium). The authors thank the staff of the Dairy Campus (Lelystad, the Netherlands) for technical support during the experiment.

\section{REFERENCES}

Ackman, R. G., and J. C. Sipos. 1964. Application of specific response factors in the gas chromatographic analysis of methyl esters of fatty acids with flame ionization detectors. J. Am. Oil Chem. Soc. 41:377-378.

Andersen, J. B., T. G. Madsen, T. Larsen, K. L. Ingvartsen, and M. O. Nielsen. 2005. The effects of dry period versus continuous lactation on metabolic status and performance in periparturient cows. J. Dairy Sci. 88:3530-3541.

Annen, E. L., R. J. Collier, M. A. McGuire, J. L. Vicini, J. M. Ballam, and M. J. Lormore. 2004. Effect of modified dry period length and bovine somatotropin on yield and composition of milk from dairy cows. J. Dairy Sci. 87:3746-3761.

Bradley, A. J., J. E. Breen, B. Payne, and M. J. Green. 2011. A comparison of broad-spectrum and narrow-spectrum dry cow therapy used alone and in combination with a teat sealant. J. Dairy Sci. 94:692-704.

Bradley, A. J., and M. J. Green. 2004. The importance of the nonlactating period in the epidemiology of intramammary infection and strategies for prevention. Vet. Clin. North Am. Food Anim. Pract. 20:547-568.

Capuco, A. V., R. M. Akers, and J. J. Smith. 1997. Mammary growth in Holstein cows during the dry period: Quantification of nucleic acids and histology. J. Dairy Sci. 80:477-487.

Chouinard, P. Y., V. Girard, and G. J. Brisson. 1997. Performance and profiles of milk fatty acids of cows fed full fat, heat-treated soybeans using various processing methods. J. Dairy Sci. 80:334-342.

Collier, R. J., E. L. Annen, and A. C. Fitzgerald. 2004. Prospects for zero days dry. Vet. Clin. North Am. Food Anim. Pract. 20:687701.

Collier, R. J., E. L. Annen-Dawson, and A. Pezeshki. 2012. Effects of continuous lactation and short dry periods on mammary function and animal health. Animal 6:403-414.

CVB (Centraal Veevoederbureau). 2005. Veevoedertabel. Gegevens over chemische samenstelling, verteerbaarheid en voederwaarde van voedermiddelen. CVB, Lelystad, the Netherlands. de Feu, M. A., A. C. O. Evans, P. Lonergan, and S. T. Butler. 2009. The effect of dry period duration and dietary energy density on milk production, bioenergetic status, and postpartum ovarian function in Holstein-Friesian dairy cows. J. Dairy Sci. 92:6011-6022.

Dix Arnold, P. T., and R. B. Becker. 1936. Influence of preceding dry period and of mineral supplement in lactation. J. Dairy Sci. 19:257-266.

Grummer, R. R., and R.R. Rastani. 2004. Why reevaluate dry period length? J. Dairy Sci. 87(E. Suppl.):E77-E85.

Grummer, R. R., M. C. Wiltbank, P. M. Fricke, R. D. Watters, and N. Silvio-Del-Rio. 2010. Management of dry and transition cows to improve energy balance and reproduction. J. Reprod. Dev. 56(Suppl.):S22-S28.

Gulay, M. S., M. J. Hayen, K. C. Bachman, T. Belloso, M. Liboni, and H. H. Head. 2003. Milk production and feed intake of Holstein cows given short (30-d) or normal (60-d) dry periods. J. Dairy Sci. 86:2030-2038.

Gümen, A., R. R. Rastani, R. R. Grummer, and M. C. Wiltbank. 2005. Reduced dry periods and varying prepartum diets alter postpartum ovulation and reproductive measures. J. Dairy Sci. $88: 2401-2411$

Klusmeyer, T. H., A. C. Fitzgerald, A. C. Fabellar, J. M. Ballam, R. A. Cady, and J. L. Vicini. 2009. Effect of recombinant bovine somatotropin and a shortened or no dry period on the performance of lactating dairy cows. J. Dairy Sci. 92:5503-5511.

Kuhn, M. T., J. K. Hutchison, and H. D. Norman. 2005. Minimum days dry to maximize milk yield in the subsequent lactation. Anim. Res. 54:351-367.

Littell, R. C., G. A. Milliken, W. W. Stroup, and R. D. Wolfinger. 1996. SAS System for Mixed Models. SAS Institute Inc., Cary, NC.

Mantovani, R., S. Sgorlon, L. Marinelli, L. Bailoni, G. Bittante, and G. Gabai. 2010. Oxidative stress indicators and metabolic adaptations in response to the omission of the dry period in dairy cows. J. Dairy Res. 77:273-279.

Neave, F. K., F. H. Dodd, and R. G. Kingwill. 1966. A method of controlling udder disease. Vet. Rec. 78:521-523.

Pezeshki, A., J. Mehrzad, G. R. Ghorbani, B. De Spiegeleer, R. J. Collier, and C. Burvenich. 2008. The effect of dry period length reduction to 28 days on the performance of multiparous dairy cows in the subsequent lactation. Can. J. Anim. Sci. 88:449-456.

Pezeshki, A., J. Mehrzad, G. R. Ghorbani, H. R. Rahmani, R. J. Collier, and C. Burvenich. 2007. Effects of short dry periods on performance and metabolic status in Holstein dairy cows. J. Dairy Sci. 90:5531-5541.

Rastani, R. R., R. R. Grummer, S. J. Bertics, A. Gümen, M. C. Wiltbank, D. G. Mashek, and M. C. Schwab. 2005. Reducing dry period length to simplify feeding transition cows: Milk production, energy balance, and metabolic profiles. J. Dairy Sci. 88:1004-1014.

Santschi, D. E., D. M. Lefebvre, R. I. Cue, C. L. Girard, and D. Pellerin. 2011a. Incidence of metabolic disorders and reproductive performance following a short (35-d) or conventional (60-d) dry period management in commercial Holstein herds. J. Dairy Sci. 94:3322-3330.

Santschi, D. E., D. M. Lefebvre, R. I. Cue, C. L. Girard, and D. Pellerin. 2011b. Economic effect of short (35-d) compared with conventional (60-d) dry period management in commercial Canadian Holstein herds. J. Dairy Sci. 94:4734-4743.

Schlamberger, G., S. Wiedemann, E. Viturro, H. H. Meyer, and M. Kaske. 2010. Effects of continuous milking during the dry period or once daily milking in the first 4 weeks of lactation on metabolism and productivity of dairy cows. J. Dairy Sci. 93:2471-2485.

Steeneveld, W., Y. H. Schukken, A. T. M. van Knegsel, and H. Hogeveen. 2013. Effect of different dry period lengths on milk production and somatic cell count in subsequent lactations in commercial Dutch dairy herds. J. Dairy Sci. 96:2988-3001.

Stefanov, I., B. Vlaeminck, and V. Fievez. 2010. A novel procedure for routine milk fat extraction based on dichloromethane. J. Food Compost. Anal. 23:852-855.

Tamminga, S., W. M. Van Straalen, A. P. J. Subnel, R. G. M. Meijer, A. Steg, C. J. G. Wever, and M. C. Blok. 1994. The Dutch 
protein evaluation system: The DVE/OEB system. Livest. Prod. Sci. 40:139-155.

Van Es, A. J. H. 1975. Feed evaluation for dairy cows. Livest. Prod. Sci. $4: 95-107$.

van Knegsel, A. T. M., H. Van den Brand, J. Dijkstra, S. Tamminga, and B. Kemp. 2005. Effect of dietary energy source on energy balance, production, metabolic disorders and reproduction in lactating dairy cattle. Reprod. Nutr. Dev. 45:665-688.

van Knegsel, A. T. M., H. van den Brand, J. Dijkstra, W. M. van Straalen, M. J. W. Heetkamp, S. Tamminga, and B. Kemp. 2007a. Dietary energy source in dairy cows in early lactation: Energy partitioning and milk composition. J. Dairy Sci. 90:1467-1476.

van Knegsel, A. T. M., H. van den Brand, J. Dijkstra, W. M. van Straalen, R. Jorritsma, S. Tamminga, and B. Kemp. 2007b. Effect of glucogenic vs. lipogenic diets on energy balance, blood metabolites, and reproduction in primiparous and multiparous dairy cows in early lactation. J. Dairy Sci. 90:3397-3409.
Van Vuuren, A. M., C. J. Van der Koelen, H. Valk, and H. De Visser. 1993. Effects of partial replacement of ryegrass by low protein feeds on rumen fermentation and nitrogen loss by dairy cows. J. Dairy Sci. 76:2982-2993.

Watters, R. D., J. N. Guenther, A. E. Brickner, R. R. Rastani, P. M. Crump, P. W. Clark, and R. R. Grummer. 2008. Effects of dry period length on milk production and health of dairy cattle. J. Dairy Sci. 91:2595-2603.

Watters, R. D., M. C. Wiltbank, J. N. Guenther, A. E. Brickner, R. R. Rastani, P. M. Fricke, and R. R. Grummer. 2009. Effect of dry period length on reproduction during the subsequent lactation. J. Dairy Sci. 92:3081-3090.

Wolff, R. L., C. C. Bayard, and R. J. Fabien. 1995. Evaluation of sequential methods for the determination of butterfat fatty acid composition with emphasis on trans-18:1 acids. Application to the study of seasonal variations in French butters. J. Am. Oil Chem. Soc. $72: 1471-1483$. 